\title{
Najstarsze miejskie szpitale polskiego Wilna (do 1939 r.)
}

\author{
Oldest, municipal hospitals in Polish Vilnius until 1939
}

\begin{abstract}
Summary
Hospital care in Vilnius has a long tradition, going back more than 300 years. Some people claim that one of the first care and treatment facilities in Central and Eastern Europe was located in Vilnius. That institution was the local St. Jacob's hospital, which after more than 90 years of operation, i.e. in 1799, received that name. The same hospital continued operation until the year 2005, when a decision was made to finally close it down.

By mid $19^{\text {th }}$ century, due to increasing demands in hospital care, as well as increased social needs, many other similar institutions were soon established, among them the "Sawicz" hospital and the Jewish hospital, which continued to operate and grow into the times of the Second Polish Republic. Władysław Zahorski wrote about the origins of the first hospitals in Vilnius already in the interwar period, however his focus was on the early days of local treatment facilities.

The article aims to describe the history of the oldest municipal hospitals in Polish Vilnius in the interwar period, up until the year 1939. The foundation of the article is established by using historic archives of the City Hall that are currently located in the Lithuanian Central State Archives (Lietuvos Centrinis Valstybes Archyvas) and in the Special Collection of the General Medical Library, together with old calendars, periodicals, and studies on the subject.
\end{abstract}

Slowa kluczowe: szpitale, Wilno, personel medyczny, lekarze

Key words: Vilnius, hospital care, interwar period, doctors

Funkcjonowanie opieki szpitalnej w Wilnie ma swoje długą, bo przeszło 300-letnią tradycję. Bowiem, jak twierdzą niektórzy ${ }^{1}$, w tym

${ }^{1}$ Informacja pochodząca z: „Tygodnik Wileński” 2013, nr 653, 21-27.03.2013, http:// www.wilnoteka.lt/artykul/biurowce-zamiast-szpitala-sw-jakuba [dostęp 2.05.2021]. 
mieście miała powstać jedna z pierwszych placówek opiekuńczo-lecznicza Europy Środkowo-Wschodniej. Placówką tą był tamtejszy szpital św. Jakóba, któremu po przeszło 90 latach, tj. w 1799 r., nadano to wezwanie. Prowadzono w nim leczenie aż do roku 2005, kiedy to zadecydowano o jego likwidacji.

W ślad za tą placówką, z powodu rosnących potrzeb leczniczych i społecznych, w połowie XVIII w. powstawały kolejne tego typu instytucje, m.in. szpital „Sawicz”, żydowski, w których działalność kontynuowana i rozwijana była w czasach II Rzeczypospolitej. O genezie działalności pierwszych wileńskich szpitali pisał jeszcze w okresie międzywojnia Władysław Zahorski², koncentrując się jednak na początkowym czasie istnienia tamtejszych placówek leczniczych.

W artykule podejmuję próbę dotarcia do materiałów archiwalnych najstarszych szpitali miejskich polskiego Wilna, szczególnie w czasach międzywojennych aż po 1939 r. Podstawą są dokumenty ówczesnego magistratu, przechowywane obecnie w Państwowym Archiwum w Wilnie - Lietuvos Centrinis Valstybes Archyvas i w Zbiorach Specjalnych Głównej Biblioteki Lekarskiej, a także dawne kalendarze i czasopiśmiennictwo czy opracowania na ten temat.

\section{Szpital św. Jakóba (warunki i profil działalności)}

Jak wspomniano, pierwsza wzmianka o najstarszym szpitalu, pod późniejszym wezwaniem św. Jakóba, pochodzi z roku 1703. Był to wtedy jednak jeszcze przytułek przeznaczony, jak zaznaczono, dla sześciu „bab” i tyluż „dziadów”, założony, na wileńskich Łukiszkach, przy kościele św. Jakóba i Filipa. Przytułek powierzony został opiece dominikanów. Do założenia placówki, przez ofiarowanie na ten cel 4 tys. zł, miał się przyczynić pisarz ziemski Michał Ślizień, którego pałac znajdował się w sąsiedztwie świątyni³ ${ }^{3}$ Od $1799 \mathrm{r}$. placówka spełniała funkcję szpitala generalnego ${ }^{4}$. Po 10 latach, od 1809 r., opiekę nad chorymi przebywającymi u św. Jakóba przejęły szarytki, które posługę pielęgnacyjną sprawowały do $1867 \mathrm{r}^{5}{ }^{\text {Sio- }}$ stry szarytki powróciły do pracy w szpitalu w dwudziestoleciu międzywojennym.

${ }^{2}$ W. Zahorski, Pierwsze szpitale wileńskie, „Pamiętnik Wileńskiego Towarzystwa Lekarskiego" 1925, t. 1, s. 65-72.

${ }^{3}$ Informacja..., op. cit.

${ }^{4}$ Szpital generalny powstał z połączenia innych, likwidowanych przez zaborcę rosyjskiego przyklasztornych przytułków. W. Zahorski, Przewodnik po Wilnie, wyd. IV, Wilno 1827, s. 65.

${ }^{5}$ Informacja..., op. cit. 
Z początkiem XX w. szpital zlokalizowany przy kościele św. Jakuba i Filipa posiadał wileński adres: ul. Kazańska $8^{6}$. Od 1919 r. lekarzem naczelnym był tam dr Zygmunt Zawadzki ${ }^{7}$. Czterech innych lekarzy pełniło obowiązki ordynatorów oddziałów szpitalnych. Wśród nich w tym czasie byli: A. Waszkiewicz, J. Padwiński, J. Michniewicz, S. Leszande (?) ${ }^{8}$. Zatrudniono też 7 felczerów, akuszerkę, 14 pielęgniarek i służbę pomocniczą (gospodarczą, w tym intendenta) ${ }^{9}$. Po dwóch latach powiększyła się liczba personelu o jednego ordynatora, akuszerkę, personel pomocniczo-gospodarczy ${ }^{10}$.

Szpital w latach 20., pod zmienionym w nowej rzeczywistości adresem: ul. 3 Maja $8^{11}$, zajmował kilka obiektów, w których rozmiesz-

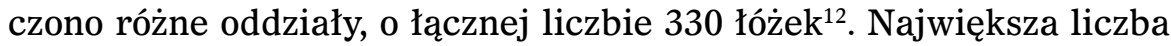
- 130 łóżek - znajdowała się na chirurgii. Czynne też było ambulatorium dentystyczne, ginekologiczne i otolaryngologii. W szpitalu istniała również szkoła akuszerek i apteka ${ }^{13}$.

Tabela 1. Oddziały szpitalne u św. Jakóba w 1921 r.

\begin{tabular}{|l|l|c|}
\hline \multicolumn{1}{|c|}{ Lp. } & \multicolumn{1}{c|}{ Oddziały } & Liczba łóżek \\
\hline 1. & Wewnętrzny & 70 \\
\hline 2. & Chirurgiczny & 130 \\
\hline 3. & Ginekologia & 10 \\
\hline 4. & Położnictwo & 20 \\
\hline 5. & Neurologia & 20 \\
\hline 6. & Ch. Umysłowych & 80 \\
\hline Łącznie & & $330^{*}$ \\
\hline
\end{tabular}

* W październiku 1921 r. wykazano stan 331 chorych. Ibidem, k. 91. Źródło: na podstawie: LCVA, sygn. 64/19/20, k. 90.

Rok później, jesienią 1922 r. z kierownictwem szpitala i władzami magistratu, w tym szefostwem sekcji zdrowia, prowadzono rozmowy s. 140 .

${ }^{6}$ Według danych z roku 1911. Por. Kalendarz Wileński informacyjny 1911, rocz. VI,

7 W 1911 r. pełnił funkcję ordynatora oddziału wewnętrznego w szpitalu św. Jakóba. Kalendarz Wileński informacyjny na 1911, s. 144.

${ }^{8}$ Imion nie udało się ustalić.

${ }^{9}$ Lietuvos Centrinis Valstybes Archyvas, dalej zwane LCVA, sygn. 64/19/34, k. 10-11.

${ }^{10}$ LCVA, sygn. 64/19/20, k. 90.

${ }^{11}$ Por. Kalendarz Wileński, informacyjny na rok 1928, rocz. XXIII, s. 96.

12 Według danych zamieszczonych w „Tygodniku Wileńskim” w 2013 r. cały szpital zajmował 1,5 ha gruntów, znajdować się na tym terenie miało pięć obiektów - gmachów przeznaczonych na cele lecznicze. Informacja..., op. cit.

${ }^{13}$ Ibidem, k. 5. 
w sprawie umiejscowienia u św. Jakóba niektórych klinik powstającego w Wilnie Uniwersytetu Stefana Batorego. W ramach uzgodnionych planów w jednym $\mathrm{z}$ podominikańskich, przykościelnych budynków umieszczono klinikę neurologiczną prof. dr. Stanisława Władyczki. $\mathrm{Na}$ ten cel zaadaptowano parter i piętro tego obiektu ${ }^{14}$. Na piętrze ulokowano trzy sale chorych oraz pracownie: badań klinicznych, histologicznych oraz gabinet elektryzacji. Na parterze pomieszczono cztery sale chorych i gabinet lekarski. Łącznie od 1924 r. można było w oddziale rozlokować 50 chorych ${ }^{15}$. Podobne na tym terenie przeznaczenie, z tą samą liczbą miejsc dla chorych, znalazła I klinika wewnętrzna prof. dr. Zenona Orłowskiego ${ }^{16}$. 25 miejsc rozdysponowano dla kobiet i tyleż samo dla mężczyzn. Przy czym sześć pokoi zostało zaadaptowanych dla części kobiecej, a o dwa więcej przewidziano dla odcinka męskiego. Pomieszczenia te różniły się jednak wielkością, a zatem możliwością rozmieszczenia w nich łóżek szpitalnych i - jak się okazuje - samym przeznaczeniem. W oddziale bowiem $\mathrm{w}$ ramach istniejącej kubatury wydzielono też część wnętrz na gabinet rtg., pracownie, pokoje pomocnicze (lekarski, profesorki i dla pielęgniarek). Personel medyczny obydwu klinik nie był jednak usatysfakcjonowany z lokalizacji. Obiekty poklasztorne nie były dostosowane do warunków leczenia: ciemne sale, wąskie korytarze, niewygodne do transportu zarówno chorych, jak i sprzętu medycznego. Panowała ciasnota. Trudności sprawiał też brak odpowiedniego miejsca na przygotowanie posiłków i prowadzenie kuracji dietetycznej, ważnej w tym czasie ${ }^{17}$.

$\mathrm{Z}$ racji zaś kilkuwiekowego istnienia obiekty te wymagały nie tylko adaptacji, ale także ciągłych remontów. Padały zastrzeżenia co do stanu sufitów, ogrzewania ${ }^{18}$. Podobne warunki, a co za tym idzie - konieczność podjęcia naprawy wielu pomieszczeń - panowały też w oddziałach części miejskiego szpitala. Napraw podjęto się w roku 1922 dzięki staraniom naczelnego lekarza i poparciu władz miasta. Ograniczono je jednak do remontu oddziału dla psychicznie chorych, poprawiając częściowo jego wygląd. Sprawa tego oddziału była szczególnie ważna ze względu na jego użyteczność dla mieszkańców województwa. Korzystać bowiem $\mathrm{z}$ jego pomocy mogło 2 tys. chorych zarejestrowanych (według danych

${ }^{14}$ LCVA, sygn. 175 ap.I,AB nr 125, k. 220-220a.

${ }^{15}$ S. Trzebiński, Wydział Lekarski USB w latach 1919-1929, [w:] Księga pamiatkowa ku uczczeniu CCCL Rocznicy założenia i X wskrzeszenia Uniwersytetu Wileńskiego. Dziesięciolecie 1919-1929, t. II, Wilno 1929, s. 447-448.

${ }^{16}$ LCVA, sygn. 175 ap III, IX B nr 18/1, k. 43.

${ }_{17}$ S. Trzebiński, op. cit., s. 430.

${ }^{18}$ Zbiory Głównej Biblioteki Lekarskiej, dalej GBL, GBL 1/993, t. 8 (brak pag.). 
z 1927 r.) - wilnian i zamiejscowych. Aczkolwiek przy okazji prac remontowych ubyło kilka pomieszczeń oddziału na rzecz innych instytucji leczniczych ${ }^{19}$. Prace remontowe były ograniczone, nie dotyczyły innych części szpitala św. Jakóba, co - jak się wkrótce okazało - byłoby niezbędne. Powodem nieobjęcia renowacją pozostałych oddziałów były zapewne wtedy względy finansowe, mimo że remont poprzedzony został sporządzeniem dość ambitnych planów, jeszcze w roku 1921. Dotyczyły one starań o pozyskanie subsydiów, pożyczek na rzecz odbudowy po działaniach wojennych kilku instytucji wileńskiego lecznictwa. Łącznie dyrekcje wileńskich szpitali, w tym najstarszych: św. Jakóba i „Sawicz” oraz żydowskiego, zamierzały pozyskać na ten cel kwotę $3 \mathrm{mln} \mathrm{mk}^{20}$. Kwoty przeznaczone m.in. na odbudowę zniszczeń powojennych tych placówek miały zostać włączone do preliminarza Departamentu Spraw Wewnętrznych ${ }^{21}$. Brak jednak dalszych wiadomości o rzeczywistym finansowym zasileniu funduszy poszczególnych szpitali na remonty. Co więcej, kwestie związane z poprawą warunków leczenia nie zostały, jak się okazało, rozwiązane, bo nadal były monitowane w następnych latach przez dyrekcje tych placówek. W tej sprawie zachował się np. protokół z 17 października 1924 r., w którym odnotowano poważne zaniedbania budowlane w głównym gmachu szpitala. Zgłoszono w nim pęknięcia na ścianach i sklepieniu wirydarza. Odnotowano też, że miejsca uszkodzeń nie zostały „objęte kapitalnym remontem w 1921”. W ramach natychmiastowych napraw zarządzono podmurowanie fundamentu uszkodzonych ścian i podwiązanie pękniętego sklepienia żelaznymi ankrami ${ }^{22}$. Podobne wady zgłaszane były przez kierownictwo oddziału psychiatrycznego. Ze strony oddziału monitowano w 1927 r. konieczność naprawy grożących zawaleniem sufitów, zniszczonych podłóg, a nawet poprawy ogólnego stanu sanitarnego oddziału oraz wentylacji. Domagano się przy tej okazji oddania odebranych pięć lat wcześniej pomieszczeń, o czym wspomniano powyżej ${ }^{23}$. Wystąpiono w związku z tym do prezydenta Wilna i naczelnego lekarza w mieście o wyasygnowanie 2 tys. zł na „pilną potrzebę” niszczejącego oddziału psychicznie chorych, ale także oddziału chirurgicznego. Zamierzano również w ramach tych środków dokonać remontu ogrodzenia szpitala ${ }^{24}$. Z mniejszych inwestycji dwa lata wcześniej udało się zorganizować przy oddziale położniczym m.in.

\footnotetext{
${ }^{19}$ LCVA, sygn. 64/19/340, k. 562.

${ }^{20}$ LCVA, sygn. 64/10/313, k. 9.

${ }^{21}$ Ibidem.

${ }^{22}$ LCVA, sygn. 64/19/338, k. 382.

${ }^{23}$ LCVA, sygn. 64/19/340, k. 562.

${ }^{24}$ Ibidem, k. 570.
} 
salę dla noworodków, nadto uzupełnić braki w wyposażeniu, zakupić 50 łóżek sprężynowych ${ }^{25}$. W sprawie zaś stanu oddziału chirurgicznego i części operacyjnej zachował się protokół ustaleń z 9 października 1927 r., w którym stwierdzono potrzebę ,usunięcia gospodarczych budynków i stajni położonej przed projektowanymi salami operacyjnymi (od strony północno-zachodniej Wilji)". Zgłoszono nadto konieczność zwiększenia możliwości lokowania chorych w oddziale i powiększenia kompleksu sal operacyjnych. Lecz miało się to odbyć kosztem oddziału (m.in. przez likwidację pomieszczeń pod nr 9 i 5). Na parterze zgłoszono potrzebę urządzenia sali septycznej i przylegających do niej pokoi pomocniczych (z instrumentami do sterylizacji, gabinetu lekarskiego i przedoperacyjnych z umywalnią). Zakładano też urządzenie identycznych pomieszczeń na pierwszym piętrze. W ramach zamierzeń przedstawiono też konieczność doprowadzenia do szpitala sieci gazowej, należytego oświetlenia elektrycznego, ogrzewania i wentylacji ${ }^{26}$. Jednakże pierwotne plany, podpisane m.in. przez opiniodawcę prof. USB dr. Kornela Michejdę, dotyczące oddziału chirurgicznego zmierzały do poprowadzenia szerzej zakrojonej rozbudowy oddziału. Przewidywano nawet budowę nowego pawilonu z podziałem na część aseptyczną i septyczną. Uwzględniono w nim dokonanie rozdziału pacjentów na przedoperacyjnych i pooperacyjnych i urządzenie sali dla ciężko chorych i umierających oraz zainstalowanie „wyciągu do przewożenia chorych na łóżku" 27 .

$\mathrm{Z}$ treści materiałów archiwalnych szpitala ze schyłku lat 20. i początków 30. nie wynika, że zrealizowano działania doprowadzające do wprowadzenia tych inwestycji, w konsekwencji większych zmian. Podejrzewać też można, że przynajmniej w końcu lat 20. ograniczane były nawet przyjęcia nowych pracowników do szpitala. Pewnym wyjątkiem było zatrudnienie od 1 grudnia 1928 r. dr. Mieczysława Trzeciaka na stanowisko ordynatora wspomnianego oddziału chirurgii ${ }^{28}$. Zdarzało się też, że ustanawiano stanowiska bez wynagrodzenia. W tej sprawie zachowało się pismo z 7 kwietnia 1927 r. skierowane do lekarza naczelnego o następującej treści: „Proszę o ustalenie w szpitalu św. Jakóba, przy oddziale położniczym stanowiska pediatry bez po-

${ }^{25}$ LCVA, sygn. 64/19/37, k. 171.

${ }^{26}$ LCVA, sygn. 64/19/340, k. 653.

${ }^{27}$ Ibidem, k. 654.

${ }^{28}$ Mieczysław Trzeciak 1889-1940 (zastrzelony w Twerze), https://www.muzeumwkaliszu.pl/wspomnienie-o-mieczyslawie-trzeciaku.html; https://muzeawielkopolski.pl/ kolekcje [dostęp 2.05.2021]. 
borów”29. Jako kandydata sugerowano dr Krystynę Stawiarską, która wtedy faktycznie już „prowadziła oddział noworodków”30.

W efekcie utrzymane zostały: stan obiektów z lat ubiegłych, ale też - poza pewnymi wahaniami - liczba rocznie przyjmowanych do szpitala chorych. Identyczna była również, jak poprzednio, liczba czynnych co do specjalności oddziałów szpitalnych.

Likwidacji za to poddano istniejące tam od początków lat 20. Kliniki, tj. neurologiczną i wewnętrzną. Powodem miały być trudne warunki nieodpowiadające, jak argumentowano, wymogom „stawianym zakładom uniwersyteckim", a nawet, jak zaznaczono, urągające wszelkim zasadom, a nawet warunkom, jakie występowały w szpitalach prowincjonalnych $^{31}$. Z inwestycji poprawiających stan jednej z klinik, a przynajmniej polepszających wygląd, udało się dokonać jedynie przeróbek w gabinecie lekarskim oddziału kobiecego, wymienić podłogę drewnianą na cementową $\mathrm{w}$ miejscu przeznaczonym na jadalnię oddziału kobiecego ${ }^{32}$. W latach 30 . XX w. sytuacja obydwu klinik nadal nie ulegała poprawie. Jak lakonicznie odnotowano w sprawozdaniu Wydziału Lekarskiego USB z roku akademickiego 1929/1930, „brak środków uniemożliwił kontynuowanie remontu"33. Podejrzewać można, że liczono się już wtedy z reorganizacją katedry i kliniki neurologicznej, umiejscowionej u św. Jakóba i ewentualnym przeniesieniem i połączeniem jej z kliniką psychiatryczną, co nastąpiło ostatecznie w marcu 1934 r. ${ }^{34}$ Dodać można, że wkrótce prof. dr Orłowski, dotychczasowy szef I kliniki wewnętrznej, został z końcem roku akademickiego 1933/1934 przeniesiony w stan spoczynku, uzyskując prawo do zaopatrzenia emerytalnego. Natomiast klinika chorób wewnętrznych u św. Jakóba przestała funkcjonować ${ }^{35}$.

$\mathrm{W}$ drugiej połowie lat 30 . sytuacja w szpitalu u św. Jakóba była nadal trudna, zwłaszcza w okresie kryzysu gospodarczego w latach 1933-1936. Z inwestycji ograniczano się, pomimo zgłaszanych koniecznych napraw, do niewielkich poprawek, reperacji ${ }^{36}$. W sprawozdawczości z lat 1933-1935 figurowały one dotąd pod nazwą „odnawiania”

${ }^{29}$ LCVA, sygn. 64/19/340, k. 11.

${ }^{30}$ Ibidem.

31 W. Jakowicki, Sprawozdanie Wydziału Lekarskiego 1929/1930, „Pamiętnik Wileńskiego Towarzystwa Lekarskiego" 1930, z. 4-5, s. 375.

${ }^{32}$ LCVA, F. 175, ap. 3, I X B nr 89, k. 26; Ibidem, F. 175, ap. I, A b nr 161, k. 130. Por. też W. Jakowicki, op. cit.

${ }^{33}$ LCVA, F. 175, ap. I, A b nr 313, k. 187.

${ }^{34}$ B. Borysowicz, Dr Jerzy Borysowicz jeden z lekarzy wileńskich 1904-1980, „Czas (Nasz Czas)” 2003, nr 36 (odbitka artykułu).

${ }^{35}$ LCVA, sygn. F. 175, ap, I, B b nr 705, k. 75.

${ }^{36}$ LCVA, sygn. 64/19/277, k. 65. 
pomieszczeń, w tym bielenia sufitu oddziałów: wewnętrznego, chirurgicznego i położnictwa, malowania lamperii, drzwi czy podłóg ${ }^{37}$. Do początków lat 30. funkcję dyrektora nadal sprawował Z. Zawadzki ${ }^{38}$, który był jednym z najdłużej pełniących tę funkcję lekarzy w szpitalu. Następnie stanowisko to pełnił dr Wacław Bądzyński, podobnie jak jego poprzednik specjalista chorób wewnętrznych ${ }^{39}$. Pojawiają się też na początku lat 30. nazwiska nowych specjalistów, także ordynatorów, w tym dr. Florjana, Felicjana Świeżyńskiego leczącego choroby płuc, nosa i uszu ${ }^{40}$ i dr. Józefa Kucharskiego - ordynatora chirurgii ${ }^{41}$. W ostatnim roku przez wybuchem wojny odnajdujemy nazwisko dr. Ludwika Łukowskiego - specjalistę chorób dzieci ${ }^{42}$. Obowiązki dyrektora szpitala pełnił już wtedy Marjan Siedlecki ${ }^{43}$.

\section{Szpital „Sawicz" (pomoc i opieka specjalistyczna)}

Nazwa Szpitala pochodzi od nazwiska zasłużonego dla miasta i tej placówki rodu Sawicz herbu Sulima i jej przedstawiciela z poł. XVIII w. płk woj. nowogródzkiego Józefa Sawicz-Korsaka. Szpital ten ufundowany został w 1744 r. przez biskupa Bogusława Gąsiewskiego. Od początku istnienia oddany był pod opiekę sióstr miłosierdzia. Z tej też racji figurował często pod nazwą szpitala sióstr miłosierdzia. Należał do instytucji, gdzie wykłady kliniczne dla studentów Uniwersytetu Wileńskiego prowadził na początku XIX w. prof. dr Józef Frank ${ }^{44}$.

Najstarszy adres szpitala, odnotowany jeszcze w roku $1911 \mathrm{w} \mathrm{Ka}$ lendarzu Wileńskim informacyjnym, to ul. Bakszta 2, i ta nazwa utrzymała się przez cały okres dwudziestolecia międzywojennego ${ }^{45}$. Pierwszym naczelnym lekarzem szpitala w XX w., tj. od 1 maja 1919 r., był dr Bernard Hłasko (specjalista z okulistyki) ${ }^{46}$. W tym czasie zatrud-

37 Ibidem.

${ }^{38}$ Księga adresowa miasta Wilna 1931, Wileński kalendarz informacyjny, rocz. XXVI, k. 98. s. 94.

${ }^{39}$ Księga adresowa $m$. Wilna 1933. Wileński kalendarz informacyjny, rocz. XXVIII,

${ }^{40}$ Ibidem, s. 96.

${ }^{41}$ Kalendarz wileński, Informator 1929. Księga adresowa $m$ Wilna, rocz. XXIV, s. 100; Księga adresowa miasta Wilna 1933..., rocz. XXVIII, k. 90.

${ }^{42}$ Księga adresowa miasta Wilna 1939, rocz. XXXIV, s. 94.

${ }^{43}$ Ibidem, s. 98.

${ }^{44}$ W. Zahorski, Pierwsze szpitale wileńskie..., op. cit., s. 82; B. Urbanek, Sytuacja epidemiologiczna Wilna l. 20 XX w. [w:] M. Fic, J. Lusek (red.), Rok 1921 na kresach wschodnich i zachodnich, Bytom-Katowice 2021, s. 415.

${ }^{45}$ Kalendarz Wileński informacyjny na rok 1911, rocz. VI, s. 140.

${ }^{46}$ B. Hłasko na początku 1926 r. został odwołany ze służby miejskiej „wobec niezdolności jego do pracy”. LCVA, sygn. 64/19/349, k. 3. 
niono też trzech ordynatorów, specjalistów z zakresu chorób skórnych i wenerycznych. Byli to: dr Bolesław Hanusowicz, dr Witold Wołodźko i dr Janina Piotrowicz-Jurczenko. W skład personelu szpitala wchodziło ponadto 4 felczerów, 10 pielęgniarek, intendent i odźwierny ${ }^{47}$.

$\mathrm{W}$ opinii W. Zahorskiego już w latach 20. placówka wymagała, podobnie jak szpital św. Jakóba, kapitalnego remontu i środków na jego przeprowadzenie ${ }^{48}$, o co zresztą, jak już wspomniano, zabiegano. Mieściła się ona bowiem, jak pisał Stanisław Trzebiński, w „starym budynku”, kilkakrotnie przebudowanym, urządzonym na 200-250 tóżek ${ }^{49}$. Sale chorych różnej wielkości, jak zaznaczano: ciemne, z małymi oknami, bez dodatkowej wentylacji. Opalane były przy pomocy pieców. Ogólna liczba sal i „,pokoi” przekraczała 100. Położenie szpitala na wspomnianej ul. Bakszta - również ciemnej i wąskiej, usytuowanej w dzielnicy gęsto zabudowanej, ale - jak stwierdził S. Trzebiński - utrzymanej „niechlujnie” ${ }^{50}$. Odczuwano też braki w inwentarzu i bieliźnie szpitalnej ${ }^{51}$.

Pierwotnie, po ocenie z 23 czerwca 1919 r., zamierzano przeznaczyć budynek szpitalny na zakład anatomii opisowej przyszłego instytutu weterynarii Wydziału Lekarskiego USB. Projekt jednak nie został zrealizowany i szpital o profilu skórno-wenerycznym pozostawał nadal w swej blisko 200-letniej siedzibie ${ }^{52}$. W tej sprawie w notatce ze szpitala skierowanej do sekcji zdrowia magistratu odnotowano: od 24 grudnia 1920 r. „(...) funkcjonuje normalnie tj. po przeniesieniu żołnierzy do szpitala [wojskowego, na Antokolu? - przyp. autora]" 53 .

Pomimo dość trudnej sytuacji, w tym warunków zarówno lokalowych, jak i w zakresie wyposażenia, już w początkowym okresie dwudziestolecia pojawiły się pozytywne oceny dotyczące pracy personelu w szpitalu. W zachowanym wniosku do miejskiego Działu Dobroczynności z 13 września 1919 r. zwrócono się „o wyznaczenie nagrody (...) dla Zofji Urbanowicz, pielęgniarki przy wydziale ocznym w Szpitalu Sawicz, która z poświęceniem się spędzała noce pielęgnując chore na oczy dzieci zakładów miejskich" ${ }^{4}$.

\footnotetext{
47 LCVA, sygn. 64/19/34, k. 13.

48 W. Zahorski, op. cit., s. 82.

49 S. Trzebiński, op. cit., s. 382.

50 Ibidem.

51 LCVA, sygn. 64/19/20, k. 91.

52 S. Trzebiński, op. cit.

53 LCVA, sygn. 64/19/317, k. 5.

${ }^{54}$ LCVA, sygn. 64/19/38, k. 136.
} 
Z początkiem lat 20. szpital dysponował 220 łóżkami przeznaczonymi dla chorych na schorzenia skórne, weneryczne i oczne. Ponadto czynna była przychodnia na te schorzenia oraz Komitet obyczajowy do zwalczania prostytucji ${ }^{55}$. Według danych z $1921 \mathrm{r}$. (z października) porad okulistycznych (zapewne głównie pod kątem panującej wtedy jaglicy) udzielono 41116 osobom, a pod względem chorób skórno-wenerycznych przebadano 7577 zgłoszonych do obserwacji ${ }^{56}$.

Liczba chorych w szpitalu od stycznia 1921 r. wynosiła 189. Jak informowały dalej władze miejskie, pacjentów „codziennie przybywa (...) i spodziewano się, że dojdzie (...) do dawnego stanu szpitala św. Łazarza [tj.] 250 zwłaszcza, że dołączono oddział oczny"57.

Tabela 2. Oddziały szpitala „Sawicz” w 1921 r.

\begin{tabular}{|l|l|c|}
\hline \multicolumn{1}{|c|}{ Lp. } & \multicolumn{1}{c|}{ Oddziały } & Liczba łóżek \\
\hline 1. & ch. skórnych & 60 \\
\hline 2. & ch. wenerycznych & 140 \\
\hline 3. & ch. ocznych & 20 \\
\hline razem & & 220 \\
\hline
\end{tabular}

Źródło: LCVA, sygn. 64/19/20, k. 91.

Lecz pojawiły się trudności związane ze zwolnieniami personelu. Z ogólnej liczby 53 pracowników pozostało 36. Akcji ograniczania wydatków na te cele, zmniejszania liczby zatrudnionych towarzyszyły protesty ${ }^{58}$. Zwrócono się zatem $\mathrm{z}$ prośbą o zaprzestanie zwolnień i przedłużenie angaży aż do 1 czerwca 1921 r. Argumentowano, że nadal zwiększać się będzie liczba chorych ${ }^{59}$. Ostatecznie władze wyraziły zgodę, a nawet zaakceptowały zatrudnienie „dodatkowego personelu”, tj. dwóch pielęgniarek, praczki i robotnika ${ }^{60}$. Udało się także usprawnić w szpitalu system kanalizacji ${ }^{61}$. Starano się o uzupełnienie akcesoriów gospodarczych i sanitarnych, niezbędnych w oddziałach ${ }^{62}$.

${ }^{55}$ LCVA, sygn. 64/19/20, k. 91.

${ }^{56}$ Ibidem.

57 Ibidem.

${ }^{58}$ LCVA, sygn. 64/19/317, k. 152-153.

${ }^{59}$ Ibidem, k. 6.

${ }^{60}$ Ibidem, k.12.

${ }^{61}$ Ibidem, k. 171.

${ }^{62} \mathrm{~W}$ zamówieniu sprzętowym szpitala z dn. 12 III 1924 r., skierowanym do Sekcji Zdrowia magistratu, zawarta została uwaga następującej treści: „(...) zaznaczyć muszę spluwaczek, koszów do odpadów może zastąpić jedynie (...) postawienie wiader emalio- 
Zgłaszano konieczność remontu łaźni oddziału wenerycznego ${ }^{63}$. Zwrócono się też do sekcji zdrowia magistratu Wilna o wyasygnowanie 1 tys. zł na zakup nowej lampy rtg. w Berlinie i niezbędnych do niej urządzeń, „(...) zamiast wentylatorów elektrycznych z których czasowo szpital musi zrezygnować" ${ }^{4}$. $\mathrm{Z}$ powodów braku aparatury pracownia rtg. była bowiem unieruchomiona przez miesiąc, chorzy narzekali na przestoje i „straty kasy (...), niemożność leczenia skórzanych chorych" ${ }^{65}$. Do zakupu prawdopodobnie nie doszło, aparaturę i niezbędne przybory rtg. uzyskano ze szpitala św. Jakóba ${ }^{66}$. Jak można podejrzewać, trudności finansowe wymuszały wprowadzanie w szpitalu różnych ograniczeń, często pod presją magistratu wileńskiego. Dnia 12 maja 1926 r. szef sekcji zdrowia Wilna informował o „przekroczeniu ceny dziennego wyżywienia chorych (...)", określając ten fakt jako „niedopuszczalny”, zalecając zarazem „zmniejszać odpowiednio racje pożywienia by cena nie przekraczała 93 gr. Największe oszczędności da się przypuszczalnie osiągnąć na zmniejszeniu racji mięsa" ${ }^{67}$. Niejako $\mathrm{w}$ postscriptum ze strony intendentury szpitala dodano: „bułki będą wydawane chorym tylko $\mathrm{w}$ dni świąteczne a postne obiady trzy razy tygodniowo" 68 .

Innym trudnym problemem do rozwiązania był pobyt w szpitalu poprzednich pacjentów - żołnierzy, którzy po jego opuszczeniu niepokoili personel i chorych. Lekarz naczelny złożył w tej sprawie zażalenie do sekcji zdrowia magistratu, prosząc o interwencję, argumentując następująco: „W skutek nieustających nieporządków wywoływanych przez żołnierzy, dobijających się o widzenie z chorymi prostytutkami (...) upraszam o ustanowienie przy szpitalu posterunku policyjnego"69, który wkrótce tam został umiejscowiony.

W 1925 r. brakowało w szpitalu lekarza naczelnego. Powodem było ubieganie się o tę funkcję dwóch dotychczasowych ordynatorów szpitala, tj. dr. Wołodźkiego i dr. Hanusowicza, którego popierało Stowarzyszenie Lekarzy Polaków w Wilnie ${ }^{70}$.

wanych (zamiast nocników) by wobec niechlujności leczących się każdy z tych sprzętów był przez nich używany do celów właściwych”. LCVA, sygn. 64/19/325, k. 167.

${ }^{63}$ LCVA, sygn. 64/19/57, k. 259.

${ }^{64}$ LCVA, sygn. 64/19/349, k. 195.

${ }^{65}$ Ibidem, k. 196.

${ }^{66}$ Ibidem, k. 162-163.

${ }^{67}$ LCVA, sygn. 64/19/346, k. 237.

${ }^{68}$ Ibidem, k. 240.

${ }^{69}$ LCVA, sygn. 64/19/317, k. 33.

${ }^{70}$ LCVA, sygn. 64/19/325, k. 8, 20. 
W 1926 r. objął tę godność dr Kazimierz Dąbrowski/Dąbkowski specjalista chorób oczu i pełnił ją do 1931 r. ${ }^{71}$ Dwa lata później przejął ją wspomniany dr Hanusowicz - specjalista chorób skórnych i wenerycznych ${ }^{72}$. Po kilku latach funkcję tę sprawował już dr Wołodźko, również specjalista z tej dziedziny, dotąd ordynator oddziału, pretendujący do tej roli kilka lat wcześniej. Jego nazwisko jako lekarza naczelnego zostało odnotowane w Księdze adresowej miasta Wilna z 1939 r. ${ }^{73}$

Lekarz naczelny był odpowiedzialny za całość funkcjonowania placówki zarówno w sprawach merytorycznej opieki nad pacjentami, jak i organizacyjnych czy materialnych ${ }^{74}$. Prócz lekarza naczelnego pracowało w szpitalu czterech ordynatorów, kierujących pracą w poszczególnych oddziałach i działach szpitala. Ponadto zatrudnionych było 6 felczerów, od 10 do 12 pielęgniarek, personel administracyjno-biurowy liczył 6 osób (w tym intendent, dozorca) ${ }^{75}$. W latach 1933-1936 kwoty przeznaczone na personel ulegały niewielkiemu wzrostowi. Wyjątkiem w tym przypadku były uposażenia lekarskie, które np. w roku 1935/1936 były nawet niższe od wyjściowego z lat 1933/1934. Nastąpił za to wzrost sumy przeznaczonej na pobory personelu pomocniczego, trudno jednak z przytoczonych danych wywnioskować, jaką grupę zawodową i liczbę osób zmiany te obejmowały. Od lat 1935-1936, po czasach kryzysu, stopniowo wzrastały wydatki na działalność leczniczą ${ }^{76}$. Dodać warto, że liczba chorych w szpitalu nie przekraczała 220 osób, tj. stanu planowego, a nawet 200. Najczęściej, np. na początku 1928 r., kształtowała się od 140 do 193 leczonych rok później ${ }^{77}$. Można przypuszczać, że sytuacja mogła kształtować się podobnie w latach 30 . XX w.

Tabela 3. Wydatki na uposażenia pracowników szpitala „Sawicz”, lata 1933-1936

\begin{tabular}{|c|l|c|c|c|}
\hline Lp. & \multicolumn{1}{|c|}{$\begin{array}{c}\text { Uposażenia } \\
\text { pracownicze w latach }\end{array}$} & $\begin{array}{c}\text { Lata } \\
1933 / 1934\end{array}$ & $\begin{array}{c}\text { Lata } \\
1934 / 1935\end{array}$ & $\begin{array}{c}\text { Lata } \\
1935 / 1936\end{array}$ \\
\hline 1 & Lekarzy & 15602 & 19960 & 14225 \\
\hline 2 & Personelu pomocniczego & 10685 & 11565 & 14275 \\
\hline
\end{tabular}

Źródło: LCVA, sygn. 64/19/277, k. 79.

${ }^{71}$ LCVA, sygn. 64/19/34, k. 109, 138, 155. Kalendarz Wileński, informacyjny na rok 1929. Ksiega adresowa miasta..., s. 104; Ksiega adresowa miasta Wilna 1931 Kalendarz Wileński informacyjny..., s. 98.

${ }^{72}$ Ksiegga adresowa $m$ Wilna 1933..., s. 98.

${ }^{73}$ Księga adresowa miasta Wilna 1939, rocz. XXXIV, k. 94.

${ }^{74}$ LCVA, sygn. 64/19/22, k. 3.

${ }^{75}$ LCVA, sygn. 64/19/20, k. 91. LCVA, sygn. 64/19/57, k. 259.

${ }^{76}$ LCVA, sygn. 64/19/277, k. 79, 81 .

77 LCVA, sygn. 64/19/70, k. 228, 607; LCVA, sygn. 64/19/94, k. 432. 
Tabela 4. Wydatki szpitalne w latach 1933-1936

\begin{tabular}{|c|c|c|c|c|}
\hline Lp. & Wydatki & $\begin{array}{c}\text { Lata } \\
1933 / 1934\end{array}$ & $\begin{array}{c}\text { Lata } \\
1934 / 1935\end{array}$ & $\begin{array}{c}\text { Lata } \\
1935 / 1936\end{array}$ \\
\hline 1. & przybory, narzędzia & 779 & 1250 & 1400 \\
\hline 2. & biblioteka & 43,25 & 200 & 200 \\
\hline 3. & żywność & 35979,29 & 35590 & 38325 \\
\hline 4. & lekarstwa & 7480,98 & 11860 & 12775 \\
\hline 5. & bielizna & 2535.87 & 2340 & 4200 \\
\hline 6. & umeblowanie & 234 & 760 & 1420 \\
\hline
\end{tabular}

Źródło: LCVA, sygn. 64/19/277, k. 81.

Danych z późniejszych lat (do 1939 r.) nie udało się pozyskać z dokumentacji źródłowej.

\section{Szpital Żydowski - trzeci z najstarszych wymienionych (specyfika społeczna placówki)}

Początki szpitala umiejscowionego naprzeciwko synagogi chóralnej sięgają 1794 r. Mieścił się tam wtedy jednak tzw. hekszesz, przytułek dla ubogich ${ }^{78}$. Jego twórcami według W. Zahorskiego było żydowskie bractwo szpitalne, które dom przeznaczony na szpital zakupiło i w 1805 r. „gruntownie przerobiło”. Na modernizację przeznaczono część dochodu „krobkowego”79. W 1865 r. budynek szpitala został przebudowany kolejny raz, wtedy według projektu Jana Lewickiego. W jego zabudowaniach zlokalizowano szkołę, aptekę i kuchnię, na drugim piętrze umiejscowiono dużą salę chorych. 26 lat później obiekt według projektu Połozowa został powiększony ${ }^{80}$. W 1911 r. adresem szpitala była ul. Pozawalna ${ }^{81}$. Jednym $\mathrm{z}$ pierwszych lekarzy naczelnych w XX w. (dane z 1911 r.) był dr Adolf Kohan, specjalizujący się w chirurgii i chorobach ,gardlanych, usznych i nosowych”"

Okazało się jednak, że wykorzystywanie obiektu, po przez przeszło 100 latach, od powstania było trudne, szpital wymagał bowiem

${ }^{78} \mathrm{https} / /$ sztetl.org.pl/en/towns/v/1044-vilnius/113-heritage-sites/30561-jewish-hospital -vilnius-pylimo-g-38 [dostęp: 6.05.2021].

${ }^{79}$ Rodzaj czynszu za dzierżawę. https://books,google.pl>books. Dodatek do gazety Kuryera Litewskiego. Wilno 4 I 1829 i tu zarządzenie z 22 XII 1928 r. generalnego sekretarza Łaski [dostęp: 7.05.2021]; https://books.google.pl>books Dodatek do gazety „Kuryera Litewskiego” 5 VI 1855 i tu: Od Wileńskiego Gubernialnego Rzadu... $29 \mathrm{~V}$ 1855. W. Zahorski, Pierwsze szpitale wileńskie..., op. cit., s. 55.

${ }^{80}$ The Jewish hospital..., op. cit.

${ }^{81}$ Kalendarz wileński. Informacyjny 1911, rocz. VI, s. 140.

82 Ibidem. 
kapitalnego remontu ${ }^{83}$. Już w 1914 r. stwierdzano, że jego mury zaczęły osiadać, obserwowano liczne zarysowania na ścianach. Komisja badająca stan obiektu zgłosiła konieczność wzmocnienia ścian. Lecz wtedy z uwagi na sytuację robót nie wykonano. Ponownie powrócono do sprawy w roku 1920, powstały bowiem na skutek działań wojennych nowe pęknięcia w konstrukcji, zagrażające chorym. Szef sekcji technicznej miasta nakazał nawet usunięcie chorych i podjęcie robót. Kosztorys na remont szacowano na sumę $285489 \mathrm{mp}^{84}$. Brak dokumentacji uniemożliwia dokonanie oceny ewentualnych napraw czy renowacji budynku podjętej w tym czasie.

Wiadomo natomiast, że po wojnie, w latach 1921-1922, funkcję lekarza naczelnego pełnił dr Wilhelm Załkinda, jego zastępcą był dr Abraham Wirszubski ${ }^{85}$. Lokalizacją szpitala pozostawała wtedy ul. Zawalna $42^{86}$. Zatrudnionych w placówce było trzech lekarzy: dr Vasey Zalrindson, dr Chorzon Zarcyn, dr Maciej Giszowicz. Pracowało tam też pięciu felczerów, dwie akuszerki, 11 pielęgniarek, dwie sanitariuszki i siła apteczna ${ }^{87}$. Personel opiekował się przeciętnie 160-175 pacjentami ${ }^{88}$ leczącymi się $\mathrm{w}$ następujących oddziałach: chirurgicznym, wewnętrznym, położniczym, ginekologicznym, chorób psychicznych ${ }^{89}$. Przy czym stan łóżek tzw. etatowych obliczono tylko na $100^{90}$. Bywało jednak, że liczba chorych przekraczała nawet 200 osób $^{91}$, a np. w 1925 r. w listopadzie wyniosła wspomnianych już 175 wszystkich pacjentów w szpitalu ${ }^{92}$. Stan ten miał też wpływ na warunki ich pobytu, które ogólnie, jak wzmiankowano, nie były zadowalające. W $1927 \mathrm{r}$. ponownie sygnalizowano potrzebę przeprowadzenia napraw, w tym „konieczne przerobienie stropu sali operacyjnej, zmiany zgniłych belek [instalacji], nowych podłóg”93. Zgłoszono

${ }^{83}$ W. Zahorski, op. cit.

${ }^{84}$ LCVA, sygn. 64/19/315, k. 120.

${ }^{85}$ LCVA, sygn. 64/19/321, k. 127; sygn. 69/19/315, k. 10. Dane z 1921-1922 r. Dr W. Załkinda prawdopodobnie wywodził się z wileńskiej rodziny handlowców, właścicieli czteropiętrowego gmachu, istniejącego w 1. 70. XIX w. przy rogu ul. Wielkiej i Rudnickiej. W początkach XX w. mieściła się tam sala teatralna, hotel. https://sztetl.org.pl/ en/towns/v/1044-vilnius/113-heritage-sites/30561-jewish-hospital-vilnius-pylimo-g-38 [dostęp 6.05.2021].

${ }^{86}$ Dane z 1925. Kalendarz Wileński Informacyjny na 1925, rocz. XX, s. 138.

${ }^{87}$ LCVA, sygn. 64/19/315, k. 10.

${ }^{88}$ Ibidem; LCVA, sygn. 64/19/37, k. 161. Zdarzało się, że w szpitalu przebywało mniej pacjentów. Por. LCVA, 64/19/94, k. 432.

${ }^{89}$ Kalendarz Wileński, informacyjny na rok 1925, rocz. XX, s. 138.

${ }^{90}$ LCVA, sygn. 64/19/94, k. 457.

${ }^{91}$ LCVA, sygn. 64/19/57, k. 227.

${ }_{92}$ Por. tabela poniżej.

${ }^{93}$ LCVA, sygn. 64/19/57, k. 313. 
zarazem brak funduszy, a na te prace remontowe konieczne było wyasygnowanie $4000 \mathrm{zł}^{94}$.

Tabela 5. Liczba oddziałów/chorych w 1925 r. (dane z 13 listopada) w Szpitalu Żydowskim

\begin{tabular}{|l|l|c|}
\hline \multicolumn{1}{|c|}{ Lp. } & \multicolumn{1}{|c|}{ Oddziały } & liczba łóżek \\
\hline 1. & Chirurgia & 55 \\
\hline 2. & Wewnętrzny & 50 \\
\hline 3. & Położniczy & 20 \\
\hline 4. & Ginekologia & 10 \\
\hline 5. & Chorób umysłowych & 40 \\
\hline Łącznie & & 175 \\
\hline
\end{tabular}

Źródło: LCVA sygn. 64/19/ 37, k. 161.

W II poł lat 20. w oddziale wewnętrznym leczono dość różne, co do pochodzenia a i lokalizacji schorzenia. Były to schorzenia zarówno jamy ustnej np. dziąseł. Ponadto choroby: górnych i dolnych dróg oddechowych o charakterze wysiękowym, ropnym, „suchym” także: dolegliwości serca, narządów trawiennych, moczowych i układu nerwowego $0^{95}$.

Tabela 6. Zabiegi chirurgiczne wykonane w 1926 r. $\left(\right.$ tab. nr 6) ${ }^{96}$.

\begin{tabular}{|l|l|c|}
\hline \multicolumn{1}{|c|}{ Lp. } & \multicolumn{1}{|c|}{ Rodzaj zabiegu } & Liczba \\
\hline 1 & „,brzucha” & 110 \\
\hline 2. & przepukliny & 99 \\
\hline 3. & „kości” & 28 \\
\hline 4. & nowotwory & 34 \\
\hline 5 & żylaki(?) odbytu & 40 \\
\hline 6. & amputacje & 19 \\
\hline 7 & „uszu” & 13 \\
\hline 8 & urologia (nerki?) & 5 \\
\hline
\end{tabular}

Źródło: LCVA, sygn. 64/19/57, k. 241.

Odnotowano założenie 64 opatrunków, z zabiegów ginekologicznopołożniczych wykonano je u 28 kobiet; w tym głównie było to wycięcie „guzów”, oraz dokonano 4 cięcia cesarskie ${ }^{97}$.

\footnotetext{
${ }^{94}$ Ibidem.

${ }^{95}$ LCVA, sygn. 64/19/94, k. 448-449.

${ }^{96}$ Wykaz według ówczesnego zapisu.

${ }^{97}$ LCVA, sygn. 64/19/57, k. 421.
} 
Na początku lat 30. wzrosła liczba pracowników, w tym zatrudniono dwóch lekarzy, zmienił się też trzyosobowy skład ordynatorów. W wykazie ordynatorów pojawiły się nazwiska dr. dr. Ownieja Załkindsona, Chonona Zarcyna, Grzegorza Giecowa. Ponadto pracowało tzw. 9 pomocników, 5 felczerów, 2 położne, 19 posługaczek, intendent, podaptekarz, nadzorczyni, 9 pracowników gospodarczych. Wykazano również tzw. personel nadetatowy: 3 siostry (pielęgniarki), 7 posługaczek i 4 pracowników „technicznych” ${ }^{98}$. Naczelnym lekarzem szpitala w 1939 r., wykazywanym w Kalendarzu Wileńskim, informacyjnym z tego roku, był/a E.(?) Sedlis - specjalista ginekologii i położnictwa ${ }^{99}$.

W podsumowaniu stwierdzić trzeba, że z racji przeszło 200-letniego istnienia wszystkie wymienione tu miejskie szpitale $\mathrm{i}$ ich kierownictwo w okresie międzywojennym borykały się z dużymi trudnościami lokalowymi, przestarzałą, niepasującą już do tych czasów konstrukcją, w dużym stopniu nadszarpniętą działaniami wojennymi. Zatem warunki, które w nich stworzono, stanowiły uciążliwość dla pracującego tam personelu i chorych. Na remonty w czasach powojennych, dewaluacji i okres kryzysu brakowało na ogół środków. Kierownictwo tych placówek mogło jedynie przeprowadzać drobne remonty, poprawiając stan użyteczności, sprowadzający się często do tzw. odświeżania. Mimo to - poza wyjątkiem likwidacji dwóch klinik USB - szpitale funkcjonowały, przyjmowano i leczono w nich chorych. Stopniowo też rozwijano niektóre dziedziny medyczne, zatrudniając lekarzy o nowych specjalnościach, stwarzając im pewną szansę rozwoju. Ogólnie jednak, co też należy dodać, personel medyczny mógł głównie w tych miejscach wykonywać standardowe zabiegi, ratując życie mieszkańcom Wilna i jego okolic. Jednak dziś tych placówek, w tym kształcie i miejscu brak ${ }^{100}$, warte są więc przypomnienia, podobnie jak i ich medyczni pracownicy.

\section{Bibliografia}

\section{Archiwalia}

Lietuvos Centrinis Valstybes Archyvas (LCVA): sygn. 64/19/20; 64/19/22; 64/19/34; 64/19/37; 64/19/38; 64/19/57; 64/19/70; 64/19/94; $64 / 19 / 148 ; 64 / 19 / 277 ; 64 / 10 / 313 ; 64 / 19 / 315 ; 64 / 19 / 317 ; 64 / 19 / 321$; 64/19/325; 64/19/338; 64/19/340; 64/19/346; 64/19/349.

\footnotetext{
${ }^{98}$ LCVA, sygn. 64/19/148, k. 148-149.

${ }^{99}$ Kalendarz Wileński, informacyjny na 1939, s. 99.

${ }_{100}$ Pozostawiono - jak w przypadku szpitala św. Jakóba - mury, czekające na lepsze czasy.
} 
LCVA, sygn. 175 ap. I AB nr 125; 175 ap. III, IX B nr18/1; F. 175, ap. 3, I X B nr 89; F. 175, ap. I, A b nr 161; F. 175, ap. I, A b nr 313; F. 175, ap. I, B b nr 705 .

Zbiory Głównej Biblioteki Lekarskiej, GBL 1/993, t. 8.

\section{Źródła drukowane}

Borysowicz B., Dr Jerzy Borysowicz jeden z lekarzy wileńskich 19041980, „Czas (Nasz Czas)” 2003, nr 36 (odbitka artykułu).

Jakowicki W., Sprawozdanie Wydziatu Lekarskiego 1929/1930, „Pamiętnik Wileńskiego Towarzystwa Lekarskiego” 1930, z. 4-5.

Kalendarz Wileński informacyjny 1911, rocz. VI.

Kalendarz Wileński, informacyjny na rok 1928, rocz. XXIII.

Kalendarz wileński, Informator 1929. Księga adresowa $m$ Wilna, rocz. XXIV.

Księga adresowa miasta Wilna1931. Wileński Kalendarz informacyj$n y$, rocz. XXVI.

Księga adresowa $\mathrm{m}$. Wilna 1933. Wileński kalendarz informacyjny, rocz. XXVIII.

Księga adresowa m. Wilna 1939,.Wileński kalendarz informacyjny, rocz. XXXIV.

Trzebiński S., Wydział Lekarski USB w latach 1919-1929, [w:] Księga pamiatkowa ku uczczeniu CCCL Rocznicy założenia i X wskrzeszenia Uniwersytetu Wileńskiego. Dziesięciolecie 1919-1929, t. II, Wilno 1929.

\section{Opracowania}

Zahorski W., Pierwsze szpitale wileńskie, „Pamiętnik Wileńskiego Towarzystwa Lekarskiego" 1925, t. I.

Zahorski W., Przewodnik po Wilnie, wyd. IV, Wilno 1827.

\section{Strony internetowe}

http://www.wilnoteka.lt/artykul/biurowce-zamiast-szpitala-sw-jakuba https://www.muzeumwkaliszu.pl/wspomnienie-o-mieczyslawietrzeciaku.html.

https://muzeawielkopolski.pl/kolekcje.

https://books,google.pl>books. Dodatek do gazety „Kuryera Litewskiego", Wilno 4.I 1829.

https://books.google.pl>books. Dodatek do gazety „Kuryera Litewskiego" 5 VI 1855.

https://sztetl.org.pl/en/towns/v/1044-vilnius/113-heritage-sites/30561-jewish-hospital-vilnius-pylimo-g-38. 